Сидоров С.В., доктор історичних наук, професор, професор кафедри оперативного мистецтвва НУО Украӥни імені Івана Черняховського (м. Київ)

\title{
ПИТАННЯ ВОСННОГО МИСТЕЦТВА У ПРАЦЯХ ВІЙСЬКОВИХ ТЕОРЕТИКІВ МИНУЛОГО: ГЕНРІХ ЖОМІНІ
}

У статті розглядаються основні аспекти воєнно-теоретичної спадщини військового теоретика ХІХ століття барона Антуана де Жоміні, який за досвідом війн епохи Просвітництвва обгрунтував необхідність теорії воснного мистещтвва та заклав ї̈ основи. Підходи Жоміні щуодо класифікаџії війн, визначення цілей, через які ведуться війни, фрормулювання найважливіших передумов військового будівнищтва, погляди щуодо методологї воєнно-історичного дослідження, сформульовані та введені у науковий обіг ним поняття та терміни не втратили своєї актуальності $і$ в сучасних умовах.

Ключові слова: Жоміні, принции воєнного мистецтвва, правила війни.

Генерал-ад’ютант, генерал від інфантерії кавалер ордена святого Андрія Первозванного Антуан Анрі барон де Жоміні (у православ’ї Генріх Веніамінович, 1779-1869) залишається одним із найвідоміших і значущих військових теоретиків минулого. 3-під його пера вийшли знаменні “Очерки воєнного мистецтва" (1838), що заклали основу професійної військової освіти у країнах Європи та Північної Америки XIX-XX ст. Як бойовий офіцер він брав участь у 12 кампаніях спочатку наполеонівської, а потім російської армій, наочно бачив зміни у воєнній теорії і практиці. Як теоретик, історик та письменник він залишив велику спадщину, вивчав досвід війн Фрідріха Великого, Семирічної війни, Французької революції, наполеонівських війн [3]. 
Жоміні належить перша спроба систематизованого аналізу воєнного мистецтва великих полководців Фрідріха Великого та Наполеона. Він заклав основи розуміння воєнного мистецтва таким, яким воно сприймалося передовими діячами його епохи, систематизував погляди епохи Просвітництва, виявив раціоналізм під час підготовки та проведення операцій. Теоретичні аспекти, розроблені Жоміні, у подальшому стали предметом всебічного вивчення, аналізу і критики фахівцями провідних військових шкіл та академій світу впродовж усього XIX століття.

Аналіз публікацій, присвячених Жоміні, свідчить, що більшість із них має переважно довідково-біографічний характер $[1 ; 3 ; 9 ; 10 ; 12 ; 15]$, зміст робіт самого Жоміні $[5 ; 6 ; 7 ; 8 ;]$ торкається подій періоду кінця XVII середини XIX століття, тому сучасні дослідники вважають їх застарілими, до спадщини цього теоретика звертаються не часто, згадують переважно правила ведення війни, основоположного принципу воєнного мистецтва, i деякі інші положення [14]. У роботі князя М. Голицина [2, с. 798-807], статтях А. Мерцалова та Л. Мерцалової [11], О. Рожинцева [12] поряд із інформацією біографічного характеру зроблено акцент на аналізі окремих теоретичних положень робіт Жоміні, але це лише незначна частина його теоретичної спадщини, що не втратила актуальності і становить науковий iнтерес.

Метою статті $є$ розкриття основних аспектів воєнно-теоретичної спадщини військового теоретика XIX століття барона Антуана де Жоміні як основоположника основ теорії воєнного мистецтва.

Жоміні народився у 1779 році в родині чиновника у швейцарському місті Пайерн, кантону Во. Військову службу почав лейтенантом у швейцарській армії у 1798 році, а завершив у 1855 році у російській генералом від інфантерії. У 1802 році у віці 23 років Жоміні видав першу серйозну працю “Трактат про великі воєнні операції”, що привернула увагу спочатку маршала Нея, а потім і Наполеона. Жоміні прийняли до лав французької армії, в якій він прослужив до 1812 року, командував 
батальйоном, потім став ад’ютантом та начальником штабу маршала Нея, отримав звання бригадного генерала, титул барона. Після вторгнення французів у Росію був комендантом Вільно, губернатором Смоленська. Відзначився в успішній для французів Буаценській битві 1913 року.

Подальша кар'єра у французькій армії завершилася після загострення непорозумінь із маршалом Л. Бертьє (начальником штабу наполеонівської армії). У серпні 1813 року Жоміні взяв на службу російський імператор Олександр I у свиту Його величності з чином генерал-лейтенанта та званням генерал-ад’ютанта [13, с. 556-557]. Під час служби у російській армії генерал Антуан-Анрі Жоміні став відомим як один із засновників та організаторів військової академії, автор численних праць 3 військової теорії та історії, написаних в основному в Росії. Жоміні залучали до планування бойових дій під час двох Кримських війн (1828-1829, 1853-1856), але за оцінками сучасників його внесок піддають сумніву. За своє тривале життя - 91 рік Жоміні опублікував більше 30 книг французькою мовою, російську він так і не засвоїв. Найзнаменнішою своєю працею Жоміні вважав коротке есе про загальні принципи війни, написане у 1804 році. Саме воно стало основою найпопулярнішої роботи швейцарського генерала - “Краткого начертания военного искусства", вперше виданого у 1830 році, російською мовою воно відоме як “Очерки военного искусства”.

Разом 3 тим ім'я Жоміні та його спадщина, переважно через суб'єктивні причини, відомі сьогодні значно менше, ніж ім'я та спадщина іншого військового теоретика, молодшого сучасника Жоміні - Клаузевица. Незважаючи на те, що багато дослідників у різні часи викривали Клаузевица у фактичному присвоєнні багатьох положень, думок та формулювань (плагіаті) швейцарського генерала, “зірка” Клаузевица, переважно 3 політичних міркувань, засяяла яскравіше, ніж Жоміні. У результаті багато зі спадщини Жоміні було сприйнято та отримало розвиток опосередковано через того ж Клаузевица. 
До недавнього часу певну увагу внеску Жоміні в науку про війну приділяли у США та Франції, однак інтерес до праць великого теоретика в останні часи відроджується.

Проблеми сучасності змушують критично переосмислити спадщину минулого. Так, Клаузевиц заперечував мораль у війні, вважав найефективнішою формою політики війну на винищення, тотальну війну. Саме ці положення стали пріоритетними для фашистської Німеччини, а Сполучені Штати перенесли їх у сферу непрямих дій (у тому числі інформаційно-психологічних), прикривши їх благою метою розповсюдження принципів демократії у світі.

Жоміні стояв на позиціях дотримання моральних норм як неодмінної запоруки успіху і у війні, і в політиці (до речі він стверджував, що буває політика без війни, а війни без політики - ні). Він відхиляв ідею тотальної війни, доводив, що військова справа 3 міркувань здорового глузду спрямована на захист суверенітету, а не для нав'язування своєї волі слабшим. “Вторгнення в землю неприятельську без справедливої причини є злочин проти людства...”, - писав він. Як розсудливий професіонал він висловлював жалкування щодо нікчемних страстей та вигод, які спонукають освічені народи в епоху масових армій до взаємного винищення, а успіхи наук, моральних та політичних, замість того, щоб привести народи до досконалого суспільного стану, повертають їх у часи гунів, вандалів, татар [3].

Справедлива війна - та, що базується на невід'ємних правах i додатково обіцяє державі вигоди, сумірні $з$ жертвами та зазнаними збитками [15, с. 128], воєнні дії не мають “виходити за межі міжнародного права", війни на винищення потрібно виключити 3 кодексу міжнародних відношень $[6$, c. 51, 52].

Саме такі гуманістичні погляди, науково обгрунтовані 3 позицій воєнної науки, відстоював Жоміні. 
Вінцем його теоретичної спадщини вважають “Очерки воєнного мистецтва", де зібрані думки Жоміні щодо різних аспектів війни та воєнного мистецтва.

На початку XIX століття домінувала думка, що “...війна є область знань, покрита мороком, яка знаходиться поза полем будь-яких закономірностей. Усі науки мають правила - лише війна не має таких правил досі” [6, с. 3].

На підставі критичного аналізу праць, спадщини великих полководців минулого та сучасності Жоміні здійснив спробу проаналізувати стан тогочасної теорії війни.

Він визнав, що мистецтво вести війну існувало завжди, стверджував, що “стратегія була така ж, як при Цезарі і Наполеоні, що вічні та непохитні принципи стратегії не залежать ні від природи, ні від організації військ”, але при цьому він констатував відсутність на той час праць, у яких викладені основні правила та основи їх застосування засобами стратегії відповідно до будь-якого театру війни.

Жоміні стверджував, що війна у сукупності - не наука, а мистецтво, що складається 3: політики війни, стратегії, великої тактики, логістики, тактики різних родів військ та інженерного мистецтва. 3 усіх теорій про воєнне мистецтво справедливою автор вважав ту, що заснована на вивченні воєнної історії, спирається на певну кількість принципів та правил ведення війни, але при цьому він віддає пріоритет військовому генію полководця, який лише керується правилами, але не скутий ними [6, с. 20-21].

Особливу увагу Жоміні приділяв аналізу перших чотирьох складових воєнного мистецтва. Під політикою війни автор розуміє міркування, за якими державна людина вирішує чи доцільно, зручно або необхідно починати війну, і що потрібно зробити для досягнення бажаної цілі. Він виділяв стратегію як мистецтво ведення війни на усьому театрі ведення дій в умовах зосередження найбільшої частини армії на важливому пункті театру воєнних дій або смуги бойових дій. 
Велику тактику він розглядав як мистецтво розташування військ на полі бою відповідно до характеру місцевості, введення їх у бій та мистецтво ведення бойових дій на місцевості, а логістика включає засоби та заходи, що дають змогу виробити плани стратегії і тактики. Іншими словами, стратегія вирішує де діяти, логістика доставляє туди війська, велика тактика визначає як застосовувати війська у бойових діях.

Жоміні вважав, що “війна є велика драма, де діють тисячі моральних та фізичних причин, але яку неможливо підвести під математичні обчислювання““ [6, с. 19]. Разом з тим на підставі власного досвіду Жоміні прийшов до висновку, що “існує невелика кількість основних правил війни, від яких не можна відступати, ігнорування їх небезпечне, а з іншого боку, використання їх завжди призводить до успіху” [6, с. 20].

Усі свої основні правила ведення війни Жоміні вивів не із абстрактних умоглядів, а із аналізу та порівняння дій двох великих полководців кінця XVIII початку XIX ст., Фрідріха II та Наполеона I. Із аналізу дій першого він зробив висновок про вигоду внутрішніх ліній, а у діях другого побачив постійне прагнення випереджати противника в наступі та діяти зосередженими силами, спрямовувати їх на вирішальні пункти театру війни. Порівнявши дії обох полководців, він помітив, що обидва прагнули рішучого бою, але Фрідріх II розділяв свої сили і діяв переважно на внутрішніх лініях, а Наполеон діяв сукупними силами, рішуче зосереджував їх на вирішальному пункті театру війни.

У результаті Жоміні визнає існування основоположного принципу воєнного мистецтва, сутність якого визначається наступними постулатами: шляхом стратегічних комбінацій послідовно направляти головні сили армії на вирішальні пункти театру війни, діяти проти комунікацій противника, зберігати свої; маневрувати так, щоб головні сили вступали в бій із частинами неприятельської армії; основну масу сил використовувати там, де очікується найімовірніший успіх; своєчасно та енергійно нарощувати зусилля [14, с. 28]. 
Одним із перших у науковій літературі він запропонував класифікацію війн залежно від їх політичного характеру, цілей та учасників.

Жоміні розглядає різні політичні обставини, завдяки яким війна може бути наступальною або оборонною, оборонною у політичному відношенні та наступальною у воєнному, доцільною, з союзниками або без них, на одному або декількох театрах, інтервенцією, агресивною або завойовницькою за іншими причинами, війною за уподобання, національною, громадянською та релігійною, подвійною, з небезпекою розв'язання двох одночасних війн.

Він визначив дев'ять типів цілей ведення війни - від “відновлення прав або їх захисту” до “прагнення завоювань та духу агресії” [6, с. 3].

Заслуговують на увагу сформульовані ним дванадцять найважливіших передумов військового будівництва, а саме: системність підходів щодо набору до армії, ii організації, створення національних резервів, налагодження навчання та виховання, запровадження субординації та пунктуальності, заснованих на переконанні, а не службовому формалізмі, зрозуміла система нагороджень, спрямована на стимулювання військових, створення спеціальних військ та їх навчання, перевага над противником в озброєнні, наявність генерального штабу, спроможного застосовувати усі ці елементи, створення системи комісаріатів, шпиталів та головного управління, системність у призначенні на командні посади та керівництві основними військовими операціями, стимулювання та підтримання бойового духу людей. До цього варто додати систему забезпечення майном та ресурсами. Жоміні підкреслює, що жодною з перерахованих умов не можна нехтувати [6, c. 20].

Жоміні піддавав різкій критиці кордонну стратегію, побудовану на розпорошенні військ, без рішучих ударних груп та завдавання рішучих ударів, протиставляв їй нову ударну систему, показав її переваги.

У своїх працях Жоміні неодноразово відзначав переваги наступального характеру дій з моральної та політичної точок зору, важливість захоплення 
ініціативи: “Наступ ....., як ініціатива рухів, завжди вигідний, особливо в стратегіi”".

Воєнне мистецтво полягає в тому, щоб кидати свої війська на вирішальний пункт, але при цьому, в першу чергу, необхідно захопити ініціативу. Хто захопив ініціативу, той завчасно знає, що він робить і чого хоче, займаючи з військами той пункт, де йому потрібно завдати удару. Хто вичікує, той завжди втрачає ініціативу: противник атакує окремі частини його армії; він не знає, ані куди противник хоче спрямувати свої зусилля, ані засобів, які потрібно йому протиставити.

Не втратили актуальності погляди Жоміні на фактори, які вирішують результат війни, що “залежить від тисячі моральних та фізичних ускладнень", впливу природних умов на хід воєнних дій тощо.

Жоміні виступав проти авантюризму, за ретельне вивчення “усіх елементів могутності і усіх засобів боротьби неприятеля у війні”, закликав під час підготовки до війни враховувати їі “мету”, “противника”, “місцевість і театр війни”, “менталітет народів” [6, с. 86, 105], акцентував увагу на тому, що “не можна нехтувати нічим, щоб мати уявлення про їх матеріальну i моральну готовність до нападу або до оборони, а також про стратегічні переваги сторін” [15, с. 88].

Спадщина Жоміні цікава як у теоретичному, так і у методологічному аспектах. У теоретичному плані, на базі дослідження історії він розвінчав судження про те, що війна є область знань, покрита мороком, що знаходиться поза будь-якими закономірностями, створив учіння про війни, зробив першу спробу поставити знання про війну на наукову основу, тим самим обгрунтував необхідність воєнної теорії.

У методологічному - зробив вагомий внесок у розроблення методології воєнно-історичного дослідження, одним із перших застосував метод порівняльного аналізу. Жоміні вважав одним із головних завдань науки виявлення зв'язків між військовими подіями та загальною ситуацією, при цьому рішуче засуджував опис фактів без узагальнення та висновків. Багато 
часу та сил він віддавав формулюванню визначень понять та термінів як основи науки, зокрема ввів до наукового обігу такі поняття, як “стратегія”, “тактика”, “театр воєнних дій”, “передній край”, “операційна зона”, “операційна лінія” тощо.

Він справедливо вважав, що воєнна історія, що супроводжується розумною критикою, є істинною школою воєнного мистецтва [15, с. 259].

Однією з головних вимог вченого до військової історіографії було критичне вивчення “великих уроків досвіду”, при цьому Жоміні ніколи не вважав себе першим в історіографії, а свої праці вінцем творіння, завжди та обов'язково посилався на своїх достойних попередників, у полеміці 3 опонентами виражав свою думку завжди стримано та безпристрасно.

Першорядне значення Жоміні надавав компетентності, вважав необхідним заохочувати та нагороджувати за “вивчення воєнних наук”, як і за “хоробрість та службову завзятість”.

“Щоб бути хорошим піхотним, кавалерійським або артилерійським офіцером, не треба у рівній мірі знати усі частини воєнного мистецтва, але для генерала або офіцера генерального штабу мати такі знання необхідно” [6, с. 31].

Військову освіту потрібно високо цінити та поважати: це єдиний спосіб зберегти знаючих та талановитих людей в армії [15, с. 104].

Таким чином, Антуан Анрі барон де Жоміні залишив велику воєннотеоретичну спадщину, у своїх дослідженнях він проаналізував досвід війн кінця XVIII - початку XIX ст., узагальнив надважливі проблеми стратегії та тактики масової армії, на базі дослідження історії створив учіння про війну, зробив першу спробу поставити знання про війну на наукову основу, обгрунтував необхідність воєнної науки.

Основні поняття та терміни, які запропонував Жоміні і ввів до наукового обігу на початку XIX століття, його погляди щодо методології воєнно-історичного дослідження (застосування порівняльного методу, опис 
подій у поєднанні 3 узагальненням та висновками) не втратили своєї актуальності і в сучасних умовах.

У цілому, заслуги Жоміні можна охарактеризувати так: він просто i ясно виклав універсальні принципи та методи воєнної науки і своїми працями поклав їй початок у їі сучасному вигляді - як системної галузі знань. Він ратував за таку військову справу, якою вона має бути, виходячи 3 принципів гуманізму та справедливості - не бажай іншому те, чого не бажаєш для себе.

Забуття свого та чужого досвіду, спадщини воєнних класиків часто призводить до відкриття істини, відомої науці ще 100-200 років тому. Не опанувавши спадщину класиків, складно вірно оцінити події, явища, особистості наступних епох. Творчість та спадщина Жоміні є яскравим підтвердженням цього, тому має важливе значення не лише для професіоналів військової справи, а й з точки зору загальнолюдської культури у цілому.

\section{Список використаних джерел i літератури}

1. Военный энциклопедический словарь. - М. : Эксмо, 2007. - С. 343.

2. Всеобщая военная история новейших времен. Часть II. Войны 1-й Французской революции и Республики 1792-1801 / составитель князь Н.С. Голицин. - СПб, 1975. - 898 с.

3. Генерал А. Жомини: [Електрон. ресурс]. - Режим доступу : http://kommandir.info/vehi-istorii/polkovodtscy-so-vsego-mira/general-antuananri-zhomini.html

4. Эман М. Вовси От Аустерлица до Тильзита: военная и литературная деятельность Антуана-Анри Жомини в 1805-07 гг.

5. Жомини $A$. Аналитический обзор главных соображений военного искусства и об отношениях оных с политикою государств. Пер. с франц. изд. 2-е. - СПб., 1836. - 342 с. 
6. Жомини А. Очерки военного искусства. Т. 1-2. Пер. с франц. M., 1939.

7. Жомини А. Политическая и военная жизнь Наполеона. Т. 1-2. Пер. с франц. - СПб., 1838. - С. 292.

8. Жомини A. Рассуждения о великих военных действиях или критическое и сравнительное описание походов Фридриха и Наполеона... Т. 1-8. Пер. с франц. - СПб., 1809-17. - 414 с.

9. Жомини А. Военная энциклопедия: Том Х. Елисавета Петровна Инициатива. - СПб., Тип. Т-ва И.Д. Сытина, 1912. - С. 400-403.

10. Жомини А. Энциклопедический словарь Брокгауза и Ефрона: Том XII (23). Жилы - Земпах. - СПб. : Семеновская Типолитография (И. А. Ефрона), 1894. - С. 34.

11. Мериалов А. Н., Мериалова Л. А. Служил России и военной науке Наследие Жомини и современность // Военно-исторический журнал. - 1994. - № 1. - C. 84-91.

12. Рожинщев A. Служа России всей душой. Андреевский кавалер барон Антуан Анри Жомини: [Електрон. ресурс]. - Режим доступу: http://otechestvoua.org/main/20063/2304.htm

13. Российский государственный военно-исторический архив, Ф.489. Оп.1. - Спр.7062. - Арк. 556-557.

14. Савкин B.E. Основные принципы оперативного искусства и тактики. - М. : Воениздат, 1972. - 376 с.

15. Энциклопедия военной мысли. - М. : Эксмо, 2002. - С. 54. 
Sydorov S.V., Doctor of Historical Sciences, Professor, Professor of Department of Operational Art of Ivan Cherniakhovskyi National Defense University of Ukraine (Kyiv)

\section{ISSUES OF MARTIAL ARTS IN THE WRITINGS OF MILITARY THEORISTS OF THE PAST: HENRI JOMINI}

The article considers the main aspects of military theoretical legacy of the XIX century military theorist Baron Antoine Jomini who proved a necessity of military art theory and set its fundamentals based on Enlightenment era wars' experiences. Jomini's approach to classification of wars, defining of war aims, formulation of the most important preconditions of military system building, views on military historical studying methodology, formulated and firstly introduced definitions and terms haven't lost their value till nowadays.

Keywords: Jomini, military art principle, rule of war. 